\title{
Isoniazid and Adverse Events
}

\section{Chatue Kamga*}

Pediatric Outpatient clinic Montigny les Cormeilles, France

*Corresponding author: Chatue Kamga, Pediatric Outpatient clinic Montigny les Cormeilles, 42 rue du General de Gaulle, France

Submission: 監August 28, 2017; Published: 眥 November 13, 2017

\section{Introduction}

Isoniazid is one first line antituberculosis essential for tuberculosis treatment in paediatric population.

Since many years a lot of articles were publicated on adverse events due to Isoniazid. According to WHO and several publication liver injuries is a most important adverse event of Isoniazid. This is a review of literature on side effect induced by INH.

\section{Method}

Review of literature from 1978 to 2010

\section{Selection criteria}

A. All reports publications articles on INH induced liver toxicity.
B. Search strategy: pubmed/medline, Google scholar, WHO site, Embase.

C. Pediatric population from 0 day to 18 years old.

\section{Exclusion criteria}

a. Adult population.

b. Articles or reports do not allow differentiating the pediatric population than adults.

c. Articles inability to differentiate side effects of isoniazid from that of other TB

Table 1: Isoniazid adverse events.

\begin{tabular}{|c|c|c|c|c|c|}
\hline Study & $\begin{array}{c}\text { Children } \mathrm{N}^{\circ} \text { Treated } \\
\text { by INH }\end{array}$ & Age (y) & INH Range & $\begin{array}{l}\text { Abnormal Hepatitis Enzyme } \\
>5 \text { Times and Symptoms }\end{array}$ & $\begin{array}{l}\text { Mild Enzyme } \\
\text { Elevated }\end{array}$ \\
\hline $\begin{array}{l}\text { Vincent Palusci et al. } \\
{[1]}\end{array}$ & 318 & $0.6-18$ & $\begin{array}{l}10-15 \mathrm{mg}(\operatorname{maxi} \\
: 300 \mathrm{mg})\end{array}$ & 1 & 2 \\
\hline Nakajo et al. [2] & 564 & $0.25-18$ & $5 \mathrm{mg} / \mathrm{kg} / \mathrm{d}$ & 1 & NA \\
\hline Col Richard et al. & 63 & $0-19$ & NA & 0 & NA \\
\hline Dash et al. & 644 & $<15$ & NA & 1 & 4 \\
\hline ROBERT S.Rapp & 116 & $0-10$ & $10-15 \mathrm{mg} / \mathrm{kg} / \mathrm{d}$ & 0 & 5 \\
\hline Iris $\mathrm{F}$ et al. & 178 & Dec-16 & $300 \mathrm{mg}$ & $\mathrm{Na}$ & $\mathrm{Na}$ \\
\hline P SPYRIDIS et al. & 239 & Sep-14 & NA & 2 & 39 \\
\hline Richard j et al. & 118 & ND & NA & ND & ND \\
\hline $\begin{array}{l}\text { CDC (SAE INH 2004- } \\
\text { 2008) }\end{array}$ & $\begin{array}{l}\text { NA(17SAE included } 2 \\
\text { children) }\end{array}$ & $<15$ & $\begin{array}{l}10-15 \mathrm{mg}(\operatorname{maxi} \\
: 300 \mathrm{mg})\end{array}$ & 2 & 0 \\
\hline $\begin{array}{c}\text { Elisabeth A et al. (New } \\
\text { York INH toxicity } \\
01 / 1993-09 / 1993 \text { ) }\end{array}$ & NA & $14-21$ & $\begin{array}{c}10 \mathrm{mg} / \mathrm{kg} / \\
\mathrm{j}(\mathrm{maxi}: 300 \mathrm{mg})\end{array}$ & ND & ND \\
\hline $\begin{array}{c}\text { Ajmad Khan. Rittesh } \\
\text { Agarwal }\end{array}$ & 695 & NA & $\begin{array}{c}5-10 \mathrm{mg} / \\
\mathrm{kg}(\operatorname{maxi} .300 \mathrm{mg})\end{array}$ & 8 & 4 \\
\hline Total & 2935 & & & 15 & 54 \\
\hline Percentage & & & & $0.56 \%$ & $2.68 \%$ \\
\hline
\end{tabular}




\section{Results}

Nine of eleven reports and articles in Table 1 have been analyzed ( 9 and 10 excluded). Of the 2935 children treated by I'INH, the percentage of patients with symptomatic liver enzymes 5 times the normal is: $0.56 \%$.We found 54 cases of moderate elevated hepatic enzyme: $2.68 \%$.

\section{Discussion}

\section{INH-associated liver injury}

It is estimated at 1 per 1000 patients (CDC report march 5, 2010). In this report only two of 7 patients were children. Symptoms such as nausea, abdominal pain, fatigue and jaundice was the key of diagnosis before laboratories analysis. In hour Table 1, we have the same results; all patients with liver injury developed the same symptomatology [1-2]. In a meta-analysis of 6 studies the incidence was $0.6 \%$ in case of use of isoniazid alone and $1.6 \%$ in combination with other TB drugs; the risk was higher at $2.7 \%$ in combination with Rifampicine in 19 reported cases. In The 2003 CDC report of 11.141 children receiving IHN incidence was estimated between $0.1-0.15 \%$. E J Forget et al estimated the adjusted incidence to $0.8 / 1000[3,4]$.

In a study of risks in tuberculosis induces liver toxicity in Japanese children [5] Katushito and Col. 117 patients aged 0-16 were included, 8 were eligible for liver toxicity criteria, none for the IHN only. After a multiple logistic regression analysis, age and pyrazinamide was associated with increased risk of hepatotoxicity [6]. The mechanism of hepatotoxicity remains unclear, a recent theory has suggested the conversion of INH to acetylisoniazid, and then to a toxic metabolite, the acetyl hydrazine, which covalently binds to macromolecules of adipose tissue [7]. In an experimental study in mice exposed to INH [7] it was found an increase in liver enzyme activity that is the biluribin glucoronyl transferase. $95 \%$ of INH is absorbed from gastrointestinal tract after ingestion, the peak concentration of IHN in children is 6 to $20 \mu \mathrm{g} / \mathrm{ml}$ (with the dose of $10-15 \mathrm{mg} / \mathrm{kg} / \mathrm{d}$ ); with the heterogeneity IHN rate acetylating. Some study in adults has suggested INH related AE and acetylation but there is not a clear relation between both $[8,9]$.

Several authors have discussed the influence of acetylators in the susceptibility to develop side effects. In an article published in 2001 Rey and neck $[10,11]$. Studied the PK of Children by the phenotype of acetylation: the plasma clearance was lower, the volume of distribution higher and half life longer in the group of slow acetylators. Mclleron Helen and colleagues [12] have studied in South Africa the PK and the NAT2 genotype in a cohort of 56 children at a dose of $4-6 \mathrm{mg} / \mathrm{kg} / \mathrm{j}$. One month after initiating treatment with isoniazid; Cmax were below reference dose in $70 \%$ of children regardless the type of acetylators $(p=0.67)$. Meanwhile children who received a daily dose of isoniazid $8-12 \mathrm{mg} / \mathrm{kg} / \mathrm{j}$ reach the peak concentration comparable to adult with the IHN $300 \mathrm{mg}$ daily regardless of the influence of NAT2 genotype $[13,14]$.

In a study of 64 children under 3 years Schaaf et al. [15] highlights the considerable difference in exposure to INH between slow and fast metabolisers, the cmax at 2 hours is double and AUC multiplied by three $(10 \mathrm{mg} / \mathrm{kg} / \mathrm{j}$ dosage used) in Fast compare to slows acetylors. Other side effects have been identified [16].

\section{Peripheral neuropathy}

(polyneuritis characterized, among others, paresthesia, muscle weakness and decreased tendon reflexes) is estimated at less than 1 to $2 \%$ of the general population has been observed in some patient groups, including adolescents, pregnant women and breastfeeding women, the elderly, the "slow acetylators" alcoholics, diabetics, people with HIV, as well as those suffering from malnutrition, renal failure or seizures. Several authors and the American Thoracic Society suggest the administration of pyridoxine (vitamin B6) in addition to the IHN if predisposition $[1,6]$.

Central nervous system: effects such as slurred speech, irritability, seizures, dysphoria, and inability to concentrate were reported but were not quantified [1]. Isoniazid can reduce the excretion of phenytoin or increase its effects. It is recommended to avoid phenytoin intoxication, one must adjust the dosage appropriately this anticonvulsant [6]. Side effects such as hypersensitivity/allergy, gastrointestinal symptoms and neurological changes in the adult literature of 0.1 to $3 \%$.

\section{Conclusion}

Tuberculosis (TB) is one of the most serious infectious diseases worldwide and a leading cause of death for nearly 3 million deaths annually. In 2013, an estimated 9.0 million people were infected with tuberculosis, and 1.5 million died from this diseases. Isoniazid, also known as isonicotinylhydrazide (INH), is one of a combined drug of tuberculosis treatment [17]. Most common adverse effects of isoniazid described in literature are peripheral neuritis and hepatitis. In our literature review; hepatotoxic see to be the most common side effect but it remain low in children [18].

\section{References}

1. Vincent JP, OHare D, Robert ML (1995) Hepaotoxicity and transaminase measurement during isoniazid chemoprophylaxix in children. Pediatr Infect Dis J 14(2): 144-148.

2. Nakajo MM, Rao M, Steiner P (1989) Incidence of hepatotoxicity in children receiving isoniazid chemoprophylaxis. Pediatr infect dis J 8(9): 649-650.

3. Byrd RB, Horn BR, Solomon DA, Griggs GA (1979) Toxic effects of Isoniazid in tuberculosis chemoprophylaxis; role of biochemichal monitoring in 1000 patients. JAMA 241(12): 1239-1241.

4. Rapp RS, Campbell RW, Howell JC, Kending EL (1978) Isoniazid hepatotoxicity in children. Am Rev Respir Dis 118(4): 794-796.

5. Ohkawa K, Hashiguchi M, Ohno K, Kiuchi C, Takahashi S, et al. (2002) Risks factors for antituberculous chemotherapy-induced hepatotoxicity in Japanese pediatric patients. Clin Pharmacol Ther 72(2): 220-226.

6. Litt IF, Cohen MI, McNamara H (1975) Isoniazid hepatitis in adolescents. J Pediatr 89(1): 133-135.

7. Spyridis P, Sinaniotis C, Papadea I, Oreopoulos L, Hadjiyiannis S (1979) Isoniazid liver injury during chemoprophylaxis in children. Arch Dis Child 54(1): 65-67.

8. OBrien RJ, Long MW, Cross FS, Lyle MA, Snider DE (1983) Hepatotoxicity 
from Isoniazid and Rifampin among children treated for tuberculosis. Pediatrics 72(4): 491-499.

9. Harrington T, Manangan L, Jereb J, Navin T, Powell K (2010) CDC: Severe Isoniazid-Associated liver injuies Among Persons being treated for latent Tuberculosis infection United states, 2004-2008. Morbidity and Mortality Weekly Report 59(08): 224-229.

10. Sullivan EA, Geoffroy P, Weisman R, Hoffman R, Frieden TR (1998) Isoniazid poisonning in New York City. J Emerg Med 16(1): 57-59.

11. Rey E, Gendrel D, Treluyer JM, Tran A, Pariente KA, et al. (2001) Isoniazid pharmacokinetics in children according to acetylor phenotype. Fundamental \& clinical pharmacology 15(5): 355-359.

12. McIlleron H, Willemse M, Werely CJ, Hussey GD, Schaaf HS, et al. (2009) Isoniazid plasma concentration in a cohort of South Africa Children with Tuberculosis : implication for international pediatric dosing guidelines. Clin Infect Dis 48: 1547-1553.
13. Devrim I, Olukman O, Can D, Dizdarer C (2010) Risks factor for Isoniazid hepatotoxicity in children with latent TB and TB: difference from adults. Chest 137(3): 737-738.

14. Stephen HG (2004) Studies of Early Bactericidal activity: new Insights into studies Isoniazid pharmacokinetics. Clinical infectious diseases 39(10): 1431-1432.

15. Schaaf HS, Parkin DP, Seifart HI, Werely CJ, Hesseling PB, et al. (2005) Isoniazid pharmacokinetics in children treated for respiratory tuberculosis. Arch dis child 90(6): 614-618.

16. Nora Morcillo (2007) Tuberculosis 2007- From basic science to patient care.

17. Sullivan EA, Geoffroy P, Weisman R, Hoffman R, Frieden TR (1998) Isoniazid poisoning in New York City. J Emerg Med 16(1): 57-59.

18. http://products.sanofi.ca/en/rifater.pdf. 